$\left.\begin{array}{c}\text { BIODIK: Jurnal IImiah Pendidikan Biologi } \\ \text { ISSN 2580-0922 (online), ISSN 2460-2612 (print) } \\ \text { Volume 6, Nomor 02, Tahun 2020, Hal. 168-175 } \\ \text { Available online at: } \\ \text { https://online-journal.unja.ac.id/biodik }\end{array}\right)$ BIODIK

Research Article

OPEN ACCESS

\title{
Profil sikap ilmiah siswa kelas VIII SMP, melalui model pembelajaran guided inquiry laboratory experiment method (gilem)
}

\section{(Scientific Attitude Profile of the Eight Grade Junior High School Students through Guided Inquiry Laboratory Experiment Method (GILEM) Instructional Model)}

\author{
Lusi Kusherawati*, Sistiana Windyariani, Setiono \\ Universitas Muhammadiyah Sukabumi
}

Jl. R. Syamsudin, S.H. No. 50, Cikole, Kec. Cikole, Kota Sukabumi, 43113 , Indonesia

${ }^{*}$ Corresponding Author: lusikusherawati22@gmail.com

\begin{tabular}{|c|c|}
\hline Informasi Artikel & ABSTRACT \\
\hline $\begin{array}{l}\text { Submit: } 13-05-2020 \\
\text { Diterima: } 07-06-2020 \\
\text { Dipublikasikan: } 19-06-2020\end{array}$ & $\begin{array}{l}\text { This study aims to seek Scientific Attitude Profile of the Eight Grade } \\
\text { Junior High School Students in Sukabumi City. This research was } \\
\text { conducted at the } 2^{\text {nd }} \text { week of October in one of the Sukabumi City } \\
\text { Junior High Schools. This research applies descriptive method. The } \\
\text { approach used in this research is a qualitative approach. The } \\
\text { population of this study were the } 65 \text { eight grade Junior High School } \\
\text { students. Samples were taken by using purposive sampling } \\
\text { technique. Data collection was performed using } 15 \text { self-assessments } \\
\text { with } 7 \text { scientific attitude indicators. The results of scientific attitude } \\
\text { profile of the eight grade Junior High School students in Sukabumi } \\
\text { City in the year of } 2019 / 2020 \text { show needs for improvements. Thus, } \\
\text { the Guided Inquiry Laboratory Experiment Method (GILEM) } \\
\text { instructional model was suggested as one alternative to be } \\
\text { implemented in order to improve the students'scientific attitude. } \\
\text { Keywords: Scientific Attitudes, Eight Grade Students. }\end{array}$ \\
\hline Penerbit & ABSTRAK \\
\hline $\begin{array}{l}\text { Program Studi Pendidikan } \\
\text { Biologi, Fakultas Keguruan dan } \\
\text { IImu Pendidikan, Universitas } \\
\text { Jambi }\end{array}$ & $\begin{array}{l}\text { Penelitian ini bertujuan untuk mengetahui profil sikap ilmiah siswa } \\
\text { kelas VIII SMP Negeri Kota Sukabumi. Penelitian ini dilaksanakan } \\
\text { pada bulan oktober di minggu ke-2 di salah satu SMP Negeri Kota } \\
\text { Sukabumi. Penelitian ini menggunakan metode deskriptif. } \\
\text { Pendekatan yang digunakan dalam penelitian ini yaitu pendekatan } \\
\text { kualitatif. Populasi pada penelitian ini adalah peserta didik kelas VIII } \\
\text { SMP Negeri Kota Sukabumi sebanyak } 65 \text { orang. Sampel diambil } \\
\text { dengan menggunakan teknik purposive sampling. Pengumpulan data } \\
\text { dilakukan dengan menggunakan self assessment sebanyak } 15 \text { soal } \\
\text { dengan menggunakan } 7 \text { indikator sikap ilmiah. Hasil penelitian } \\
\text { menunjukkan bahwa profil sikap ilmiah siswa kelas VIII SMP Negeri } \\
\text { Kota Sukabumi tahun ajaran } 2019 / 2020 \text { masih dalam kategori kurang. } \\
\text { Namun hasil tersebut masih harus ditingkatkan kembali dengan } \\
\text { menggunakan model, strategi dan pendekatan pembelajaran yang } \\
\text { mampu meningkatkan sikap ilmiah siswa. Salah satu model } \\
\text { pembelajaran yang disarankan adalan model pemebelajaran guided } \\
\text { inquiry laboratory experiment method (Gilem). } \\
\text { Katakunci: Sikap IImiah, Siswa Kelas VIII. }\end{array}$ \\
\hline
\end{tabular}


This BIODIK : Jurnal IImiah Pendidikan Biologi is licensed under a CC BY-NC-SA (Creative Commons Attribution-ShareAlike 4.0 International License)

\section{PENDAHULUAN}

Kurikulum 2013 merupakan kurikulum baru yang mulai diterapkan pada tahun pelajaran 2013 hingga saat ini, yang menjadi fokus dalam kurikulum 2013 ini yaitu mengenai adanya peningkatan dan keseimbangan antara soft skills dan hard skills. Tidak hanya itu, pada kurikulum 2013 memuat kompetensi inti diantaranya sikap, pengetahuan, dan keterampilan (Fadlillah,2014; Zulfaidhah, Z., Palenewen, E., \& Hardoko, A, 2018). Pasal 1 ayat 5 peraturan pemerintah Nomor 32 Tahun 2013 mengenai Standar Nasional Pendidikan telah menjelaskan bahwa pada dasarnya kompetensi lulusan adalah kriteria mengenai kualifikasi kemampuan yang terdiri dari sikap, pengetahuan dan keterampilan (Ristekdikti, 2016). Dalam kurikulum (2013) ini menekankan sikap sebagai bagian yang penting, siswa diharapkan mempunyai keterampilan mengembangkan pengetahuan serta sikap percaya diri yang tinggi. Sikap tersebut dapat ditemukan melalui sikap ilmiah maka dari itu sikap ilmiah sangat penting untuk dimiliki setiap siswa karena hal tersebut bermanfaat sebagai bekal melanjutkan pendidikan ke jenjang yang lebih tinggi lagi. Dengan sikap ilmiah siswa akan dapat berpikir kritis, rasional dan menggunakan logikanya untuk memecahkan masalah (Sadikin, A., Kamid, K., \& Hariyadi, B, 2013). Lebih lanjut, dengan sikap ilmiah siswa diharapkan dapat mengembangkan imajenasinya untuk menarik kesimpuland dari fakta-fakta yang ditemukkannya (Aina, M., \& Sadikin, A, 2015).

Pembelajaran IPA khususnya biologi menekankan siswa untuk saintifik proses, tidak hanya itu dalam Kurikulum (2013) juga menekankan kompetensi sikap sebagai bagian yang penting, sikap setiap siswa tentunya berbeda-beda, besar harapan dari setiap kegiatan pembelajaran yang sudah dilakukan itu dapat mengembangkan sikap setiap siswa. Menurut Depdiknas (2012), salah satu tujuan dari pembelajaran IPA khususnya dalam Biologi adalah supaya siswa memiliki kemampuan meningkatkan minat dan motivasi, menguasai konsep dan prinsip biologi serta mempunyai keterampilan mengembangkan pengetahuan dan sikap percaya diri. Sikap yang harus dimiliki siswa dalam kurikulum 2013 tersebut dapat ditemukan melalui sikap ilmiah, maka dari itu sikap ilmiah sangatlah penting untuk dimiliki semua siswa. Sikap ilmiah merupakan sikap yang dibutuhkan dalam pembelajaran biologi (Hakim, N, 2015; Wibowo, Y. G., \& Sadikin, A, 019). Sikap ilmiah merupakan sikap para ilmuan yang ditunjukan ketika melakukan kegiatan sebagai ilmuan, Mukhodaphyay (2014). Menurut Yustiana (2014) menyatakan bahwa "Sikap ilmiah adalah suatu kecenderungan, kesediaan, serta kesiapan individu dalam memberikan respons, tanggapan, atau berperilaku ilmiah". Sedangkan menurut Fakhruddin (2014) "Sikap ilmiah merupakan salah satu bentuk kecerdasan yang dapat dimiliki oleh setiap individu".

Pentingnya sikap ilmiah tersebut juga terdapat dalam pernyataan menurut para ahli diantaranya adalah: Melalui sikap ilmiah siswa dituntut berperan aktif serta 
kreatif dalam proses pembelajaran sehingga dapat membantu proses pembelajaran yang baik. Aspek dalam sikap ilmiah pada pembelajaran IPA merupakan hal yang sangat penting untuk dikembangkan, sebab sikap adalah pondasi bagi siswa untuk dapat menghargai karya orang lain serta menghargai dirinya sendiri Musyarofah (2013). Menurut Harso, dkk (2014) menyatakan bahwa: sikap ilmiah itu sangat penting dalam kehidupan bermasyarakat karena sikap ilmiah ini dapat membentuk pribadi manusia khususnya peserta didik dalam melakukan pertimbangan yang rasional pada saat mengambil suatu keputusan. Tidak hanya itu, menurut Yunita dan Fakhruddin (2014) menyatakan bahwa: setiap siswa yang mempunyai sikap ilmiah yang tinggi itu akan mendapat kelancaran dalam berpikir sehingga dapat termotivasi siswa untuk selalu berprestasi serta memiliki komitmen yang kuat untuk mencapai keberhasilan dan keunggulan dalam suatu proses pembelajaran di dalam kurikulum 2013.

Berdasarkan hasil observasi yang telah dilakukan data sikap ilmiah yang didapatkan yakni pada dasarnya sikap ilmiah sudah dilatihkan pada saat pembelajaran, namun belum terlalu efektif dalam proses dilapangannya, sebagian besar sikap ilmiah siswa rata-rata masih tergolong rendah jika dilihat melalui presentase skor rata-rata indikator sikap ilmiah. Untuk mengatasi masalah tersebut maka diperlukan model-model pembelajaran tertentu yang dapat membuat siswa antusias dalam proses pembelajaran baik di dalam kelas maupun di luar kelas serta dapat meningkatkan sikap ilmiah siswa. Sehingga peneliti tertarik untuk mengetahui profil sikap ilmiah siswa kelas VIII melalui model pembelajaran guided inquiry laboratory experiment method (gilem).

\section{METODE PENELITIAN}

Penelitian ini menggunakan metode deskriptif, menurut Sudjana, et.al (2007) menyatakan bahwa "penelitian deskriptif adalah penelitian yang berusaha mendeskripsikan suatu gejalan, peristiwa, kejadian yang terjadi pada saat sekarang". Pendekatan yang digunakan dalam penelitian ini yaitu pendekatan kuantitatif dimana pendekatan yang cenderung fokus terhadap suatu permasalahan Sugiyono (2013). Prosedur penelitian terdiri dari 3 tahap yang pertama tahap persiapan, dimana melakukan study literatur serta perumusan masalah, memilih lokasi serta subjek penelitian, merumuskan, menyusun, serta judgment instrument, merancang kegiatan belajar mengajar, izin penelitian, lalu tahap pelaksanaan, dimana melaksanakan sebuah penelitian dan tahap akhir dimana mengolah data yang diperoleh, pembahasan serta menarik kesimpulan dan saran.

Pengumpulan data dilakukan dengan menggunakan lembar self assessment, sebanyak 15 soal dengan menggunakan 7 indikator sikap ilmiah yaitu sikap ingin tahu, sikap respect terhadap data maupun fakta, sikap berfikir kritis, sikap pebemuan dan kreativitas, sikap berfikir terbuka dan bekerja sama, sikap ketekunan, dan sikap peka terhadap lingkungan sekitar. Adapun kategori kemampuan sikap ilmiah menurut Arikunto (2010) dapat dilihat pada tabel 1. 
Tabel 1. Kategori Kemampuan Sikap IImiah (Arikunto, 2010)

Persentase Kemampuan

Kategori

$81-100 \%$

$61-80 \%$

Sangat Baik

$41-60 \%$

Baik

$21-40 \%$

$0 \%-20 \%$

Cukup

Kurang

Sangat kurang

\section{HASIL DAN PEMBAHASAN}

Sikap ilmiah merupakan sikap yang diarahkan untuk mencapai pengetahuan yang objektif, tidak hanya itu sikap ilmiah diartikan sebagai tingkah laku individu atau seseorang ketika memecahkan suatu permasalahan melalui langkah ilmiah secara sistematik. Indikator yang diamati dari Sikap IImiah ini yaitu antusias mencari jawaban, antusias pada proses sains, sikap jujur, tidak memanipulasi data, mengambil keputusan sesuai fakta, menanyakan setiap perubahan atau hal baru, merubah pendapat dalam merespons fakta, menggunakan alat tidak seperti biasanya, mau merubah pendapat jika data kurang, menerima saran dari teman, tidak merasa selalu benar, berpartisipasi aktik dalam kelompok perhatian terhadap lingkungan sekitar, dan partisipasi pada kegiatan sosial. Data hasil observasi Sikap IImiah kelas VIII SMP Negeri Kota Sukabumi lihat tabel 2.

\begin{tabular}{|c|c|c|c|}
\hline NO & $\begin{array}{l}\text { Tabel 2. Hasil Sikap Ilmiah kelas VIII SN } \\
\text { Indikator Sikap IImiah }\end{array}$ & $\begin{array}{l}\text { vegerI Kot } \\
(\%)\end{array}$ & Kategori \\
\hline 1 & Antusias mencari jawaban & $27,65 \%$ & Kurang \\
\hline 2 & Antusias pada proses sains & $20,8 \%$ & Sangat kurang \\
\hline 3 & Sikap jujur & $24,95 \%$ & Kurang \\
\hline 4 & Tidak memanipulasi data & $30 \%$ & Kurang \\
\hline 5 & Mengambil keputusan sesuai fakta & $20 \%$ & Sangat kurang \\
\hline 6 & Menanyakan setiap perubahan atau hal baru & $30 \%$ & Kurang \\
\hline 7 & Merubah pendapat dalam merespons fakta & $30,8 \%$ & Kurang \\
\hline 8 & Menggunakan alat tidak seperti biasanya & $24,95 \%$ & Kurang \\
\hline 9 & Mau merubah pendapat jika data kurang & $27,45 \%$ & Kurang \\
\hline 10 & Menerima saran dari teman, & $30,8 \%$ & Kurang \\
\hline 11 & Tidak merasa selalu benar & 28,3 & Kurang \\
\hline 12 & Berpartisipasi aktik dalam kelompok & $24,15 \%$ & Kurang \\
\hline 13 & Perhatian terhadap lingkungan & $21,6 \%$ & Kurang \\
\hline 14 & Partisipasi pada kegiatan sosial & $28,3 \%$ & Kurang \\
\hline \multicolumn{2}{|c|}{ Rata-rata } & $26,41 \%$ & Kurang \\
\hline
\end{tabular}

Dari data diatas kita dapat mengkategorikan bahwa sikap ilmiah siswa kelas VIII SMP Negeri Kota Sukabumi yang memiliki kategori masih kurang. Adapun rincian dari data observasi yaitu pada indikator sikap ilmiah antusias mencari jawaban sebesar 27,65\%, sikap jujur sebesar 24,95\%, tidak memanipulasi data sebesar $30 \%$, menanyakan setiap perubahan atau hal baru sebesar $30 \%$, merubah pendapat dalam merespons fakta sebesar 30,8\%, menggunakan alat tidak seperti biasanya sebesar 24,95\%, mau merubah pendapat jika data kurang sebesar $27,45 \%$, menerima saran dari teman sebesar 30,8\%, tidak merasa slalu benar sebesar 38,3\%, berpartisipasi aktif dalam kelompok sebesar $24,15 \%$, perhatian terhadap lingkungan sebesar $21,6 \%$, partisipasi pada kegiatan social sebesar $28,3 \%$ 
dikategorikan kurang. Sedangkan yang dalam kategori sangat kurang adalah indikator antusias pada proses sains sebesar 20,8\% dan mengambil keputusan sesuai fakta sebesar $20 \%$.

Menurut Arikunto (2010) sikap ilmiah tergolong rendah apabila kurang dari 40\%. 12 aspek yang tergolong kurang yaitu antusias mencari jawaban, sikap jujur, tidak memanipulasi data, menanyakan setiap perubahan atau hal baru, merubah pendapat dalam merespons fakta, menggunakan alat tidak seperti biasanya, mau merubah pendapat jika data kurang, menerima saran dari teman, tidak merasa slalu benar, berpartisipasi aktif dalam kelompok, perhatian terhadap lingkungan, dan partisipasi pada kegiatan sosial. Sedangkan 2 aspek dikategoikan sangat kurang adalah indikator antusias pada proses sains, dan mengambil keputusan sesuai fakta. Penyebab rendahnya sikap ilmiah siswa kelas VIII SMP Negeri Kota Sukabumi ini adalah: pertama kebiasaan pembelajaran gaya lama di dalam kelas yaitu dimana guru mendominasi dalam penyampaian materi menyebabkan peserta didik tidak terbiasa mandiri dalam belajar karena selalu ber-gantung pada gurunya dan berdampak pada sikap ilmiah mereka. Seperti sikap antusias mencari jawaban, menanyakan setiap perubahan atau hal baru, perhatian terhadap lingkungan, dan partisipasi pada kegiatan sosial. Menurut Hanafiah (2009), peserta didik yang sudah terbiasa dengan pembelajaran gaya lama akan kesulitan menerapkan metode saintifik seperti indikator sikap ilmiah. Yang kedua kurangnya pelaksanaan kegiatan praktikum. Kegiatan praktikum yang dilaksanakan hanya berlangsung tiga kali dalam satu semester. Dimana, siswa hanya mengisi lks yang sudah disediakan oleh guru, dan mematuhi instruksi yang diberikan guru, sehingga siswa disisni tidak terbiasa untuk antusias pada proses sains, tidak memanipulasi data,mengambil keputusan sesuai fakta, merubah pendapat dalam merespons fakta menggunakan alat tidak seperti biasanya, mau merubah pendapat jika data kurang, dan berpartisipasi aktif dalam kelompok. Dalam Iks yang berbasis inkuiri siswa di tuntut aktif dalam kegiatannya serta mencari tahu sendiri apa yang menjadi persoalannya, tidak hanya itu dalam Iks yang berbasis inkuiri ini dapat meningkatkan sikap ilmiah siswa, Harso (2014).

Sikap ilmiah siswa yang rendah disebabkan oleh beberapa faktor meliputi: buku satu-satunya pedoman dalam pembelajaran, Azwar (2007), kebiasaan gaya pembelajaran lama, hanfiah (2009), rendahnya latar belakang sains, minimnya prasarana laboratorium, Musyarofah (2013). Pembelajaran yang hanya menekankan penguasaan konsep, serta kegiatan pembelajaran yang belum mengeksplorasi sikap ilmiah. Secara garis besar faktor yang mempengaruhi rendahnya sikap ilmiah siswa terjadi karena kurangnya optimalisasi pembelajaran yang melibatkan peran siswa, seperti pada indikator antusias mencari jawaban, antusias pada proses sains, tidak memanipulasi data, menanyakan setiap perubaahn atau hal baru, berpartisipasi aktif dalam kelompok serta partisipasi pada kegiatan social. Hasil yang didapatkan dari observasi dapat memperlihatkan bahwa siswa kurang terampil dan aktif mengikuti proses pembelajaran, siswa cenderung lebih banyak diam dan sekedar memperhatikan materi yang disampaikan oleh guru.

Sikap ilmiah merupakan sikap yang diarahkan untuk mencapai pengetahuan yang objektif, Kaur (2013), sikap ilmiah perlu dikembangkan melalui pengalaman 
langsung yang melibatkan penggunaan berbagai material dan tindakan fisik. Melalui sikap ilmiah siswa dituntut berperan aktif serta kreatif dalam proses pembelajaran sehingga, dapat membantu proses pe,belajaran yang baik, Fakhruddin (2014). Aspek dalam sikap ilmiah pada pembelajaran IPA merupakan hal yang sangat penting untuk dikembangkan, sebab sikap ilmiah adalah pondasi bagi siswa untuk dapat menghargai karya orang lain serta menghargai dirinya sendiri, Musyarofah (2013).

Model pembelajaran inkuiri merupakan salah satu model pembelajaran yang berperan penting dalam membangun keaktifan belajar siswa yang mengahasilkan keterampilan-keterampilan dalam sains dasar seperti keterampilan berinkuiri (Setiono et al., 2017). Model pembelajaran Guided Inquiry Laboratory Experiment Method (Gilem) lebih berpusat pada siswa, dimana model ini berisi arahan yang terbatas dari guru sedangkan siswa lebih bertanggung jawab serta siswa dapat merancang eksperimen mereka sendiri bukannya mengikuti proses verifikasi, mereka mencoba untuk mencapai konsep ilmiah sendiri dan mereka mengembangkan keterampilan kognitif tingkat tinggi, Blanchard (2010). Model ini diharapkan dapat memperoleh pengalaman langsung lebih mudah dalam memahami materi pelajaran yang sedang dipelajari, serta dengan model pembelajaran ini dapat membantu siswa melatih sikap ilmiahnya. Karena pada dasarnya sikap ilmiah ini ada pada saat pembelajaran berlangsung yang terdiri dari 7 indikator yaitu sikap ingin tahu, sikap respect terhadap data maupun fakta, sikap berfikir kritis, sikap penemuan dan kreativitas, sikap berfikir terbuka dan bekerja sama, sikap ketekunan dan sikap peka terhadap lingkungan sekitar. Maka dapat dilihat bagaimana sikap ilmiah siswa dan siswa tidak hanya berorientasi pada kemampuan pengetahuannya saja.

\section{KESIMPULAN}

Berdasarkan hasil observasi yang telah dilakukan tersebut maka diperoleh kesimpulan bahwa profil sikap ilmiah siswa kelas VIII SMP Negeri Kota Sukabumi tahun ajaran 2019/2020 masih dalam kategori masih kurang. Akan tetapi hasil tersebut masih dapat ditingkatkan kembali dengan menggunakan model, strategi dan pendekatan pembelajaran salah satunya. Model pembelajaran yang disarankan adalan model pembelajaran Guided Inquiry Laboratory Experiment Method (Gilem), dimana model ini mampu memberdayakan keterampilan proses sains siswa, yang menjadikan siswa lebih antusias pada proses pembelajaran baik di dalam ruangan maupun diluar ruangan.

\section{UCAPAN TERIMAKASIH}

Ucapan terima kasih saya sampaikan kepada semua pihak yang telah membantu dalam penyusunan artikel ini. 
Arikunto, S. (2010). Dasar-dasar Evaluasi Pendidikan Edisi Dua. Jakarta : Bumi Aksara.

Aina, M., \& Sadikin, A. (2015). Profil Berpikir Kreatif Mahasiswa Tipe Phlegmatis dalam Pemecahan Masalah pada Mata Kuliah Dasar dan Proses Pembelajaran Biologi. Jurnal Penelitian Universitas Jambi: Seri Humaniora, 17(1), 43489.

Azwar, S. (2007). Sikap Manusia Teori dan Pengukurannya. Yogyakarta : Pustaka Belajar.

Blanchard, M. et al. 2010. Is inquiry possible in light of accountability? : A quantitative comparison of the relative effectiveness of guided inquiry and verification laboratory instruction. Science Education, 94(4): 577-616.

Depdiknas. (2012). Tujuan dari Pembelajaran IPA. Jakarta: Departemen Pendidikan Nasional.

Fadlillah. (2014). Implementasi Kurikulum 2013. Yogyakarta : Arr-Ruzz Media.

Hakim, N. (2015). Penerapan Project-Based Learning Dipadu Group Investigetion Untuk Meningkatkan Motivasi, dan Hasil Belajar Mahasiswa Pendidikan Biologi Universitas Muhammadiyah Malang. Jurnal BIODIK, 1(1).

Hanafiah, N., \& Cucu, S., (2009). Konsep Strategi Pembelajaran. Bandung : PT Refika Aditama.

Harso, dkk. (2014). Pengaruh Model Pembelajaran Heuristik Vee terhadap Pemahaman Konsep Fisika dan Sikap IImiah Siswa Kelas X SMA Negeri 2 Langkessss Rembong. Jurnal: e-journal Program Pascasarjana. Universitas Pendidikan Ganesha Program Studi, Vol. 4, hlm. 1-12.

Kaur, Gurpreet. (2013). "Science Attitude In Relation To Critical Thinking among Teacher". Educationia Confab. 2, (8), 24-29.

Kurikulum 2013 revisi, (2014). Contoh indikator penilaian kompetensi sikap. [Online]. Tersedia: http://www.salamedukasi.com/2014/11/contoh-indikator-penilaiankompetensi.html. Diakses pada [Oktober 2019].

Mukhodaphyay, R (2014). "Science attitude-some psychometric considerations". IOSR Journal Of Humanities and social Science (IOSR-JHSS). 19, (1), 98-100.

Musyarofah, dkk. (2013). Pendidikan Karakter Terintegrasi dalam Pembelajaran IPA Guna Menumbuhkan Kebiasaan Sikap IImiah. Jurnal: Unnes Physics Education Journal. UPEJ 2 (2), hlm. 41-48.

Ristek dikti. (2016). Pasal 1 ayat 5 Peraturan Pemerintah Nomor 32 Tahun 2013 mengenai Standar Nasional Pendidikan. [Online]. Tersedia https://kelembagaan.ristekdikti.go.id/wpcontent/uploads/2016/08/PP0322013.pd f. Diakses pada [Oktober 2019].

Sadikin, A., Kamid, K., \& Hariyadi, B. (2013). Profil Berpikir Kritis Mahasiswa Tipe Phlegmatis dalam Pemecahan Masalah Biologi. Edu-Sains: Jurnal Pendidikan Matematika dan IImu Pengetahuan Alam Universitas Jember, 2(2), 59535. https://doi.org/10.22437/jmpmipa.v2i2.1670.

Setiono, Rustaman, N.Y., Rahmat, A., Anggraeni, S. (2017). Implementasi guided inquiry laboratorium pada praktikum anatomi tumbuhan. Jurnal Utile. 3, (2)195201. 
Sudjana, et.al. .(2007). Penelitian dan Penilaian Pendidikan, Bandung : Sinar Baru Algensindo.

Sugiyono. (2012). Metode Penelitian Pendidikan Pendekatan Kuantitatif, kualitatif, dan $R \& D$. Bandung : Alfabeta.

Sugiyono. (2013). Metode Penelitian Pendidikan pendekatan Kuantitatif, Kualitatif dan $R \& D$. Bandung : Alfabeta.

Wibowo, Y. G., \& Sadikin, A. (2019). Biology in the 21st-Century: Transformation in biology science and education in supporting the sustainable development goals. JPBI (Jurnal Pendidikan Biologi Indonesia), 5(2), 285-296. https://doi.org/10.22219/jpbi.v5i2.7956.

Yunita F dan Fakhruddin Z. (2014). Hubungan Antara Sikap Imliah Siswa dengan Hasil Belajar Fisika si Kelas XI IPA MA Negeri Kampar. [Online]. Tersedia: http://repository.unri.ac.id/xm/ui/bitstream/handle/123456789/1508/Jurnal\%20Fr ima\%20Yunita.pdf?sequence. Diakses pada [Oktober 2019].

Yustiana, (2014). "Peningkatan Sikap IImiah dalam Pembelajaran Biologi Kelas XI IPA melalui Penerapan Model Pembelajaran Problem Based Learning". Jurnal Biogenesis.

Zulfaidhah, Z., Palenewen, E., \& Hardoko, A. (2018). Needs Analysis in the Problem Based Learning (PBL) Model Tools and Problems Regarding 7th Grade Students' Science Learning Outcome at SMPN 2 Bongan. BIODIK, 4(1), 48-59. https://doi.org/10.22437/bio.v4i1.5508. 